\title{
HUBUNGAN SARANA SANITASI DASAR RUMAH DENGAN KEJADIAN PENYAKIT DIARE DI KELURAHAN BALAS KLUMPRIK KOTA SURABAYA TAHUN 2017
}

\author{
Rheswiken Ayu Noviandita, Imam Thohari, Marlik
}

\begin{abstract}
ABSTRAK
Derajat kesehatan masyarakat dapat di wujudkan jika masyarakat tersebut menjaga lingkungan dan berperilaku yang sehat, apabila kondisi lingkungan dan hygiene sanitasi yang kurang baik akan lebih memudahkan terkena penyakit berbasis lingkungan antara lain diare. Penyakit diare di Kelurahan Balas Klumprik tahun 2015 sampai 2016 meningkat 20 kasus. Salah satu faktor yang berkaitan dengan kejadian diare adalah sarana sanitasi dasar rumah yang meliputi penyediaan air bersih, pembuangan kotoran manusia, pembuangan air limbah dan pembuangan sampah. Tujuan penelitian ini untuk mengetahui hubungan sarana sanitasi dasar rumah dengan kejadian penyakit diare di Kelurahan Balas Klumprik Kota Surabaya.

Jenis penelitian yang digunakan adalah analitik. Pengambilan sampel menggunakan simple random sampling sebesar 204 rumah (sampel kasus 102 dan kontrol 102 rumah). Teknik pengumpulan data dengan menggunakan observasi dan angket yang kemudian di analisis menggunakan uji chi-square.

Dari hasil uji statistik didapatkan bahwa ada hubungan antara sarana pembuangan kotoran manusia dan sarana pembuangan air limbah rumah tangga dengan kejadian diare, tidak ada hubungan antara sarana air bersih, sarana pembuangan sampah rumah tangga dan sarana sanitasi dasar rumah dengan kejadian diare di Kelurahan Balas Klumprik Kota Surabaya.

Untuk itu disarankan pihak dinas kesehatan secara rutin mengadakan penyuluhan-penyuluhan mengenai penyakit berbasis lingkungan serta meningkatkan pola perilaku hidup bersih dan sehat.
\end{abstract}

Kata Kunci : Sanitasi Dasar Rumah, Penyakit diare

\section{PENDAHULUAN}

Pertumbuhan jumlah penduduk dan urbanisasi merupakan salah satu permasalahan pemukiman yang umumnya terjadi di daerah perkotaan, sehingga banyaknya masyarakat yang membangun rumah secara ilegal seperti membangun rumah di pinggir sungai, membangun rumah di pinggir rel kereta api maupun membangun rumah di atas tanah yang bukan miliknya sendiri. Pembangunan rumah tersebut dikarenakan adanya keterbatasan lahan penduduk di perkotaan. Pembangunan rumah secara ilegal akan menimbulkan kekumuhan di perkotaan yang berdampak antara lain menimbulkan berbagai penyakit dan banjir.

Penyakit diare adalah seringnya buang air besar lebih dari 3 kali dalam sehari (24 jam) dengan perubahan bentuk feses menjadi encer. Beberapa faktor yang berkaitan dengan kejadian diare yaitu kurangya sarana penyediaan air bersih, air tercemar oleh tinja, kurangnya sarana kebersihan (pembuangan tinja yang tidak hygiene), kebersihan perorangan, lingkungan yang jelek dan penyimpanan makanan yang kurang hygiene.

Menurut Langit, (2016) mengatakan kejadian diare pada balita mengalami peningkatan di setiap tahunnya. Pada tahun 2012-2014 kasus diare meningkat sebesar 289 kasus, 309 kasus, 313 kasus dan ada hubungan antara kondisi sarana penyediaan air bersih dan kondisi saluran pembuangan air limbah dengan kejadian diare pada balita di Wilayah Kerja Puskesmas Rembang 2.

Hasil data yang kami peroleh di Kelurahan Balas Klumprik penyakit diare pada tahun 2015 merupakan urutan ke 6. Pada tahun 2015 dan 2016 penyakit diare meningkat dari 582 menjadi 602 kasus (meningkat 20 kasus), rumah yang belum memenuhi syarat rumah sehat dari tahun 2015 dan 2016 juga mengalami peningkatan yaitu 304 menjadi 334 rumah (meningkat 30 rumah) dari seluruh jumlah rumah yang ada di Kelurahan Balas Klumprik, dengan 
adanya peningkatan rumah yang belum memenuhi syarat rumah sehat juga merupakan salah satu penyebab penyakit diare. Kondisi sarana sanitasi dasar rumah di Kelurahan Balas Klumprik Kota Surabaya kurang baik pada sarana penyediaan air bersih masih ada masyarakat yang menggunakan air sumur tetapi untuk menyiram tanaman dan mencuci baju saja. Sarana pembuangan sampahnya yaitu sampah terbuka dan tidak tertutup yang menjadikan tempat berkembangbiaknya vektor. Sarana pembuangan air limbah saluran atau perpipaannya tidak tertutup, menimbulkan bau juga dapat menjadi tempat berkembangbiaknya vektor serta sarana pembuangan kotoran manusia licin dan masih ditemukan serangga yang dapat menyebabkan penyakit diare. Tujuan penelitian ini adalah untuk mengetahui hubungan sarana sanitasi dasar rumah dengan kejadian penyakit diare di Kelurahan Balas Klumprik Kota Surabaya Tahun 2017.

\section{METODE PENELITIAN}

Jenis penelitian ini termasuk penelitian analitik dengan studi Case Control. Populasi sampel dalam penelitian ini jumlah rumah penderita diare, untuk sampel kontrol tetangga rumah penderita diare di Kelurahan Balas Klumprik Kota Surabaya dengan besar sampel kasus yaitu 102 rumah dan sampel kontrol 102 rumah. Metode yang digunakan yaitu observasi dan kuesioner, setelah itu data di analisis menggunakan Uji Chi-Square.

\section{HASIL DAN PEMBAHASAN}

Kualitas sarana penyediaan air bersih sebagian besar kurang baik yaitu 48,53\% (99 orang) dan 4,9\% (10 orang) yang penyediaan air bersihnya sudah baik, berdasarkan uji statistik tidak ada hubungan antara sarana penyediaan air bersih dengan kejadian penyakit diare di Kelurahan Balas Klumprik Kota Surabaya $(p=0,686>0,05)$ dikarenakan air sumur gali yang berbau hanya digunakan untuk menyiram tanaman dan mencuci baju, konstruksi sumur berlumut, sumber air minum warga masih menggunakan air isi ulang dari hasil uji laboratorium sampel air minum isi ulang yaitu tidak mengandung Escherichia Coli.

Kualitas sarana pembuangan kotoran manusia sebagian besar cukup baik yaitu $80,88 \%$ (165 orang) dan $7,84 \%$ (16 orang) yang sarana pembuangan kotoran manusia sudah baik, berdasarkan uji statistik ada hubungan antara sarana pembuangan kotoran manusia dengan kejadian penyakit diare di Kelurahan Balas Klumprik Kota Surabaya ( $p=0,031<$ $0,05)$ dikarenakan warga yang mempunyai jamban pribadi di dalam rumah namun kurang memenuhi syarat kesehatan seperti keadaan sarananya yang kotor, masih ditemukan serangga di tempat klosetnya, tidak ada penutup atau pintu, tidak beratap dan lantai tidak kedap air.

Kualitas sarana pembuangan air limbah rumah tangga sebagian besar sudah baik yaitu $52,45 \%$ (107 orang) dan 3,43\% (7 orang) yang sarana pembuangan air limbah rumah tangga kurang baik, berdasarkan uji statistik ada hubungan antara sarana pembuangan air limbah rumah tangga dengan kejadian penyakit diare di Kelurahan Balas Klumprik Kota Surabaya $(p=0,034<0,05)$ dikarenakan saluran pembuangan air limbah rumah tangga yang terbuka, keadaan pembuangan air limbahnya tidak lancar, banyak sampah di selokan sehingga menimbulkan bau yang tidak sedap dan menjadi tempat berkembangbiaknya vektor apabila musim hujan dapat menyebabkan banjir.

Kualitas sarana pembuangan sampah rumah tangga sebagian besar sudah baik yaitu $48,53 \%$ (99 orang) dan $21,57 \%$ (44 orang) yang sarana pembuangan sampah rumah tangga kurang baik, berdasarkan uji statistik tidak ada hubungan antara sarana pembuangan sampah rumah tangga dengan kejadian penyakit diare di Kelurahan Balas Klumprik Kota Surabaya $(p=0,943>0,05)$ dikarenakan sampah rumah tangga setiap harinya dibakar di lahan belakang rumahnya sehingga tidak menimbulkan tempat berkembangbiaknya vektor dan apabila rumah warga yang tidak mempunyai lahan, sampahnya setiap sore hari atau pagi hari di bawa dan dibuang di TPS wiyung sedangkan untuk rumah yang berada di perumahan 
sampahnya di angkut oleh petugas pengambil sampah setiap 2 hari sekali. Kualitas sarana sanitasi dasar rumah sebagian besar cukup baik yaitu $74 \%$ (151 orang) dan 5,9\% (12 orang) yang sarana sanitasi dasar rumah sudah baik, berdasarkan uji statistik tidak ada hubungan antara sarana sanitasi dasar rumah keseluruhan dengan kejadian penyakit diare di Kelurahan Balas Klumprik Kota Surabaya ( $p=0,756>$ $0,05)$ dikarenakan sarana penyediaan air bersih untuk sehari-hari seperti memasak menggunakan air PDAM, air minum yang dikonsumsi sehari-hari yaitu air isi ulang yang tidak mengandung Escherichia Coli, kualitas air PDAM sudah memenuhi syarat tidak berbau, tidak bewarna, tidak berasa dan aliran air lancar dan sarana pembuangan sampah setiap harinya di bakar di lahan belakang rumahnya dan rumah yang berada di perumahan sampah di angkut oleh petugas pengambil sampah setiap 2 hari sekali.

Tabel 1

HUBUNGAN SARANA SANITASI DASAR RUMAH DENGAN KEJADIAN DIARE DI KELURAHAN BALAS KLUMPRIK KOTA SURABAYA TAHUN 2017

\begin{tabular}{|c|c|c|c|c|c|}
\hline \multirow{3}{*}{ No. } & \multirow{3}{*}{$\begin{array}{c}\text { Sarana Sanitasi Dasar } \\
\text { Rumah }\end{array}$} & \multicolumn{4}{|c|}{ Kejadian Diare } \\
\hline & & \multicolumn{2}{|c|}{ Tidak Diare } & \multicolumn{2}{|c|}{ Diare } \\
\hline & & $\mathbf{n}$ & $\%$ & $\mathbf{n}$ & $\%$ \\
\hline 1. & Baik & 7 & $3,4 \%$ & 5 & $2,5 \%$ \\
\hline 2. & Cukup Baik & 76 & $37,3 \%$ & 75 & $36,8 \%$ \\
\hline 3. & Kurang Baik & 19 & $9,3 \%$ & 22 & $10,8 \%$ \\
\hline Jumla & & 102 & $50 \%$ & 102 & $50 \%$ \\
\hline
\end{tabular}

Berdasarkan tabel di atas didapatkan hasil uji statistik tidak ada hubungan antara sarana sanitasi dasar rumah keseluruhan dengan kejadian penyakit diare di Kelurahan Balas Klumprik Kota Surabaya $(p=0,756>0,05)$, dikarenakan sarana penyediaan air bersih untuk sehari-hari seperti memasak menggunakan air PDAM, air minum yang dikonsumsi sehari-hari yaitu air isi ulang yang tidak mengandung Escherichia Coli, kualitas air PDAM sudah memenuhi syarat tidak berbau, tidak bewarna, tidak berasa dan aliran air lancar dan sarana pembuangan sampah setiap harinya di bakar di lahan belakang rumahnya dan rumah yang berada di perumahan sampah di angkut oleh petugas pengambil sampah setiap 2 hari sekali.

\section{KESIMPULAN}

Kesimpulan bahwa ada hubungan antara kualitas sarana pembuangan kotoran manusia dan kualitas sarana pembuangan air limbah rumah tangga dengan kejadian penyakit diare, tidak ada hubungan antara kualitas sarana penyediaan air bersih, kualitas sarana pembuangan sampah rumah tangga dan kualitas sarana sanitasi dasar rumah dengan kejadian penyakit diare di Kelurahan Balas Klumprik Kota Surabaya.

\section{SARAN}

Lebih meningkatkan kesadaran diri untuk menjaga dan merawat lingkungan seperti tidak membuang sampah sembarangan.

\section{DAFTAR PUSTAKA}

Depkes, RI. 2011. Pengendalian Diare di Indonesia. Jakarta.

Dinas Kesehatan Kota Surabaya tahun 2015 tentang Data Penyakit Diare.

Keputusan Menteri Kesehatan RI No. 829/Menkes/SK/VII/1999 tentang Persyaratan Kesehatan Perumahan.

Langit, L. S. 2016. Hubungan Kondisi Sanitasi Dasar Rumah dengan Kejadian Diare pada Balita di Wilayah Kerja Puskesmas Rembang 2,

(April):161.http://id.portalgaruda.or g/article.php?article $=451236 \& \mathrm{val}=$ 4700.13 November 2016. 
Peraturan Menteri Kesehatan No.43 tahun 2015 tentang Hygiene Sanitasi Depot Air Minum.

Peraturan Menteri Kesehatan 429/Menkes/Per/IV/2010 tentang Persyaratan Kualitas Air Minum

Undang-undang Republik Indonesia Nomor 1 tahun 2011 tentang Pengertian Rumah.

Undang-undang Republik Indonesia Nomor 36 tahun 2009 tentang Kesehatan. I-1. 